\title{
Editorial
}

\section{Les Juges Constituants}

Several contributions to the present issue relate to the power of the constitutional courts in our modern world. Let us introduce them, first by going back in time.

Montesquieu described judges as no more than 'la bouche qui prononce lesparoles de la loi; des êtres inanimés qui n'en peuvent modérer ni la force ni la rigueur' [the mouth that pronounces the words of the law, mere passive beings, incapable of moderating either its force or rigour']; De L'esprit des lois, XI, 6, 1749). Most of us will have learned that this description represents the legal positivist view on the nature of judicial activity, which in a distorted version holds that courts are merely automatons solving disputes by simply subsuming the relevant facts under the relevant legal act. However, in the fascinating account of his search for the origin and meaning of the 'bouche de la loi' phrase in an earlier issue of this journal, Schönfeld has argued that it is not about servile submission of courts to the black letter of the law, but about their prerogative of interpretation of the law, which the King should not usurp. Schönfeld even connects the body of thought of which the bouche de la loi phrase is an exponent to the review against the US Constitution to which the United States Supreme Court submits the legislature and other state authorities. What, then, of Montesquieu's qualification of judges as mere passive beings, etc.? It was a smokescreen, it turns out, to distract the attention of French royal court. ${ }^{1}$

In the modern world, not least thanks to the influence of Montesquieu, the independence of courts is secured by constitutional and/or Treaty law and includes their prerogative to interpret the law in the cases brought before them. Following in the wake of the US, even courts in most European countries have obtained the power to exercise constitutional review. It is the same in the European legal order, if we consider, together with Andreas Voßkuhle in this issue, the European Court of Justice and the European Court of Human Rights to be constitutional courts on the basis of a broad conception of 'constitutional jurisdiction'.

${ }^{1}$ K.M. Schönfeld, 'Rex, Lex and Iudex: Montesquieu and “la bouche de la loi” revisited', EuConst 4 (2008), p. 274-301. 
Constitutional review is still on the rise and its domain continues to expand through Europe. For instance, the jurisdiction of the European Court of Justice has been extended by the Lisbon Treaty to cover police and justice cooperation in the field of criminal law. France is another case in point. Last spring, it introduced a posteriori constitutional review, complementing the a priori review instituted in 1958. The latter development is described, placed in comparative European legal context and discussed in this issue by Otto Pfersmann. Also, the review techniques become more and more refined and penetrating. Since Hans Kelsen we are used to seeing the constitutional courts described as 'negative legislatures', because of their capacity of annulling legislative acts. These days we are getting used to seeing them described as 'positive framework legislatures' ${ }^{2}$ and as 'alternative lawmakers' (Pfersmann). The former description is on account of their practice of issuing legislative injunctions by which they prescribe in more or less detail the contours of required future legislation. The latter description applies if, instead of annulling a provision, they prefer to interpret it in conformity with the constitution, which may in fact lead to substituting the provision with an alternative one.

In both cases referred to above the courts might be said to act as ordinary legislatures. France has gone a step further, by upgrading the Conseil constitutionnel, the French constitutional court, to a kind of secondary constitutional legislature. This is at least what Pfersmann contends. Since 1 March 2010 the French constitutional court may and even must decide constitutional complaints of litigants against promulgated acts of parliament transmitted to the council by (highest) ordinary courts. Transmission is excluded, however, if the allegedly unconstitutional act has been declared to be in conformity with the Constitution 'in the operative part and the motives' (emphasis added) of an earlier judgment by the Conseil constitutionnel. This formal upgrading of the reasoning of a judgment to a norm binding on ordinary courts, in Pfersmann's words, turns 'statements, expressed and written as arguments, into (secondary) constitutional provisions.' As a consequence, alongside the formal Constitution a new, 'common-law' constitution starts developing.

This is not an isolated French evolution. Preliminary judgments of the European Court of Justice, for instance, also have a precedent like quality. They have what it is called L'autorité de la chose interprétée (authority of interpretation) and not only bind the referring court, but all the courts, ${ }^{3}$ even though they are not in a hierarchical relationship to the Court of Justice. This could be said to be the distinguishing element from the English common-law (or vertical) precedent and to approach the authority of US Supreme Court judgments towards non-federal courts. It is, mutatis mutandis, the same with judgments of the European Court of

${ }^{2}$ Christian Behrendt, Le juge constitutionnel, un législateur-cadre positif (Bruylant, 2006).

${ }^{3}$ Although they always retain the right to ask a new preliminary question; ECJ 27 March 1963, Joined Cases 28-30/62, Da Costa en Schaake NV et al. v. Nederlandse Belastingadministratie. 
Human Rights. Moreover, the consistent output of judgments by these (and other) constitutional courts results in bodies of law which at least practically and sociologically may be called 'secondary constitutions'.

What Voßkuhle in this issue calls the 'common European constitutional order', the unwritten code in which the national constitutional orders and those of the European Convention and the European Union are geared to one another, can be depicted as essentially such a common-law constitution. This constitution, hovering somewhere above both the national constitutions and the different European treaties, is elaborated in collaboration between the Court of Justice, the European Court of Human Rights and the national constitutional courts. It is the product of their famous 'dialogue'.

The latter point is fully acknowledged by Voßkuhle in his contribution to this issue. He describes and analyses what he calls the Verfassungsgerichtsverbund between the Bundesverfassungsgericbt, the European Court of Human Rights and the Court of Justice, a relationship which cannot be caught in 'over-simplistic spatial and hierarchic concepts such as "superiority" and "subordination".' He praises both European Courts and emphasises that the ultra vires review and constitutional identity review that figure so prominently in the Lissabon-Urteil of the German constitutional court are not to be understood as signs of mistrust towards the Court of Justice. On the contrary, the German constitutional court is firmly committed to European integration and to the development of the common European constitutional order. Although, as he explains, the courts 'have their own prisms which reflect different (legal) views of the world' and this has led to occasional 'notes of discord', in the end these always have inspired positive developments.

These days, at least amongst lawyers, stern opponents to constitutional review are hard to find. Even the Netherlands, along with Great Britain one of the last pockets of resistance in Europe, is for the first time in its history seriously contemplating a change. A constitutional act proposing to change the Grondwet and to give all courts the power to review parliamentary acts against constitutional rights and freedoms is awaiting approval in second reading by the Dutch Parliament.

Indeed, constitutional review generally has served our societies well: it has strengthened the unity and uniformity of law and it has enhanced legal certainty and the Rule of Law.

But perhaps all that glitters is not gold. The widening authority and reach of the constitutional courts also pose certain practical and normative problems. Pfersmann, for one, concludes that while the new French a posteriori review procedure purports to enhance legal certainty and the Rule of Law, the authority given to interpretations of the Conseil constitutionnel actually weakens them, inter alia, because the developing French common-law constitution will be even harder to read and interpret than the original one. 
Furthermore, the thickening of constitutional law may affect the ability of politics to adapt to inevitable social and political change. Christian Tomuschat recently argued in Die Zeit that the Bundesverfassungsgericht, by acting as 'Praezeptor Germaniae' (tutor of the German Republic) and entangling politics in an everthicker web of detailed prescriptions, appropriates a responsibility for the shaping of the future that for both practical and democratic reasons can belong only to politics. ${ }^{4}$

The power of the constitutional courts is greatest when the possibility of overruling them remains largely theoretical. This is for instance the case in the common European constitutional order. The 'correction' of interpretations of the European Court of Human Rights and the Court of Justice require unanimity between the (member) states. Therefore it is highly improbable that the Mangold and Kücükdeveci case-law of the Court of Justice, which is so severely criticized in this issue by Mirjam de Mol for, inter alia, disregarding the balance of power between the member states and the Union, can ever be overruled. Except of course by the Court itself, whether or not in 'dialogue' with the Bundesverfassungsgerichtlater this year, the German court is scheduled to rule on a constitutional complaint aimed at Mangold.

Constituent power of the courts, in dialogue, accommodation or even collaboration, has become undeniable. It raises at least two points for scholarship to contemplate. First, what is the foundation of this power in terms of classical constitutional theory? Second, instead of or apart from the courts and their interactions: what is the relationship, in this constituent activity, between the courts and the political institutions, including the people?

JHR/WTE

\section{ADDENDUM}

Just days before this issue went to press, on 26 August 2010, the Bundesverfassungsgericht announced that several weeks earlier, on 6 July 2010, it had rejected the complaint aimed at the Mangold case-law, because even if it were ultra vires, it is not obviously so and does not structurally change the division of competences between the member states and the Union to the detriment of the former (Honeywell judgment, 2 BvR 2661/06).

\footnotetext{
4 'Die Karlsruher Republik', Die Zeit 16 May 2010
} 